Józef M. DOŁĘGA

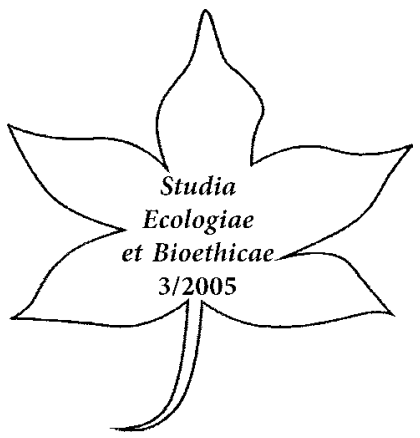

Instytut Ekologii i Bioetyki

UKSW w Warszawie

\title{
Słowo o terminie ekofilozofia
}

Termin ekofilozofia wszedł oficjalnie do słownika filozoficznego na VI Zjeździe Filozofii Polskiej w 1995 roku w Toruniu. Do Sekcji: Ekofilozofia i filozofia życia zgłoszono 29 referatów. Część z nich dotyczyła ekofilozofii. Od Zjazdu Toruńskiego termin ten zaczyna funkcjonować coraz częściej w tekstach publikowanych i w wykładach, znakiem tego są dwa numery Ateneum Kapłańskiego 138(2002)2, 139(2002)3 i cały szereg publikacji oraz wykłady kursoryczne i monograficzne w uniwersytetach i akademiach, np.: Uniwersytet Kardynała Stefana Wyszyńskiego, Uniwersytet Adama Mickiewicza, Uniwersytet Mikołaja Kopernika, Uniwersytet Warmińsko-Mazurski, Katolicki Uniwersytet Lubelski, Papieska Akademia Teologiczna, Uniwersytet Szczeciński, Uniwersytet Śląski, Uniwersytet w Bialymstoku, Akademia Podlaska, Pomorska Akademia Pedagogiczna, Politechnika Lubelska, Politechnika Łódzka, i inne. Artykuł prezentuje analizy dotyczące terminu, pojęcia, koncepcji, problematyki merytorycznej ekofilozofii, ma na celu przybliżyć Czytelnikowi zasadnicze zręby ekofilozofii.

W analizie semantycznej terminu ekofilozofia wyjdziemy od znakomitego tekstu Antoniego B. Stępnia na temat filozofii zamieszczonego w Stowniku pojęć filozoficznych ${ }^{1}$.

1. Filozofia - jak wiadomo termin ten pochodzi z języka greckiego: philosophia, $\varphi$ ı

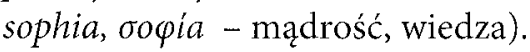

Termin ten posiada wiele odcieni znaczeń, a mianowicie:

- znaczenie najogólniejsze: wiedza o świecie, wiedza dotycząca bytu jako bytu, wiedza dotycząca przedmiotu (przedmiotów), wiedza dotycząca źródeł i granic poznania;

\footnotetext{
Słownik pojęć filozoficznych, pod red. W. Krajewskiego, WN Scholar, Warszawa 1996, 57-60.
} 
- znaczenie światopoglądowe: oznacza światopogląd zapewniający osobie ludzkiej orientacje w świecie i umożliwiający życie rozumne;

- znaczenie naukowotwórcze oznacza teorie wiedzy naukowej.

Termin sophia, oopía pierwotnie oznaczał wszelkiego rodzaju teoretyczną

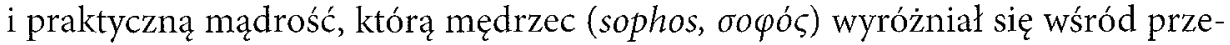
ciętnych ludzi. Nadano temu słowu znaczenie przede wszystkim teoretyczne, które umożliwiało zdobycie jakiejś umiejętności (techne, $\tau \dot{\varepsilon} \chi v \eta$ ) lub praktycznej działalności (arete, $\alpha \rho \varepsilon \tau \dagger)$. Nauczyciela tak pojmowanej wiedzy nazywano sofi-

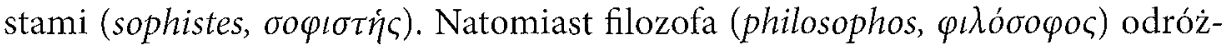
niano od sofisty i mędrca, wlaśnie filozofowie powinn zdobycia mądrości, do zdobycia wiedzy o tym, co naprawdę istnieje. W związku z tym w myśli europejskiej możemy wyróżnić przede wszystkim dwa zasadnicze znaczenia terminu filozofia:

$1^{0}$ Filozofia jako najogólniejsza nauka o świecie lub zbiór kilku ogólnych nauk filozoficznych;

$2^{0}$ Filozofia jako światopogląd przede wszystkim mający praktyczne znaczenie.

Oba te rozumienia filozofii nie są przeciwstawne, a można je rozumieć jako ujęcia komplementarne.

2. Ekofilozofia - termin składa się z trzech wyrażeń greckich:

- oikos, oĩkoৎ - oznacza: środowisko, dom; mieszkanie, siedzibę, mienie rodzinne, gospodarstwo, rodzinę;

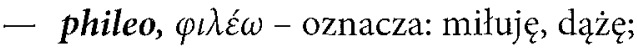

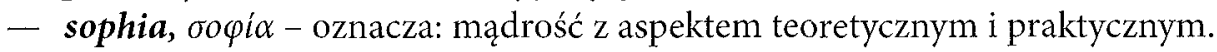
Zatem ekofilozofia, w najogólniejszym rozumieniu, jest nauką filozoficzną o środowisku. Inaczej mówiąc ekofilozofia jest nauką filozoficzną o środowisku przyrodniczym i społecznym, czyli o ekosystemie ziemskim i jego otoczeniu $z$ aspektami teoretycznymi i praktycznymi. Krócej mówiąc: ekofilozofia jest nauką o ekosystemie i jego otoczeniu. Określenia te zawierają terminy, które należy wyjaśnić, a mianowicie:

- nauka filozoficzna: charakterystyka tej nauki zawarta jest w epistemologii i metodologii filozofii, analogicznie do filozofii należy wypracować epistemologię i metodologię ekofilozofii, uwzględniając specyfikę w przyjmowanych koncepcjach tej nauki;

- środowisko: rozumiemy w ujęciu całościowym, czyli ze wszystkimi sferami, w których toczy się proces życia i istnieje człowiek, a mianowicie: atmosferą, hydrosfrą, litosferą, kosmosferą, biosferą, antroposferą;

- system $(\sigma \dot{v} \sigma \tau \eta \mu \alpha)$ : termin ten jest pomocny w opisie nie tylko różnorakich podsystemów przyrodniczych, ale również w opisie podsystemów społecznych, ekonomicznych, technicznych, przemysłowych itp. Wielki system to 
jeden wielki obiekt sterowania, który według Mieczysława Lubańskiego ${ }^{2}$ charakteryzuje się następującymi właściwościami:

- system ten składa się z podsystemów, które można wyróżnić i opisać;

- każdy z podsystemów ma własny cel działania, a jego efektywność może być oceniana w zależności od procesu sterowania;

- cały system ma ogólny cel działania, a jego efektywność ocenia się na podstawie działania podsystemów;

— w podsystemach, jak też między nimi, zachodzą liczne sprzężenia;

- w systemie istnieje hierarchiczna struktura sterowania;

- rozbudowana sieć informacyjna gwarantuje celowe funkcjonowanie i optymalizację systemu;

- w systemie obserwuje się współdziałanie ludzi, wytworów człowieka i środowiska przyrodniczego - wszystkie te elementy systemu tworzą środowisko;

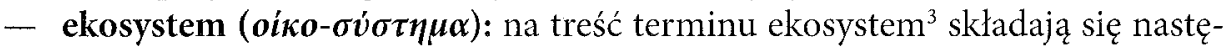
pujące elementy:

- organizmy żywe (biosfedra) - czynniki biotyczne;

- i człowiek z całą antroposferą;

- oraz czynniki abiotyczne - atmosfera, hydrosfera, litosfera, kosmosfera, magnetosfera. W poznaniu naukowym możemy prowadzić badania małych ekosystemów o dużej złożoności, oraz można rozpatrywać wielki ekosystem ziemski, uwzględniając wszystkie oddziaływania wewnętrzne oraz wpływ otoczenia na ten system, czyli najbliższego otoczenia kosmicznego Ziemi i Kosmosu;

- otoczenie: pojęcie otoczenia jest związane z rozumieniem systemu, a przez system ${ }^{4}$ rozumiemy zespół różnych elementów wzajemnie ze sobą powiązanych, na siebie oddziaływujących i stanowiących pod pewnym względem całość. Określenie to nawiązuje do filologicznego znaczenia terminu „system”

2 M.Lubański, Informacja-system, w: M.Heller, M.Lubański, S.W.Ślaga, Zagadnienia filozoficzne wspótczesnej nauki. Wstęp do filozofii przyrody, Warszawa 1982², 29-31; Kierzkowski, Elementy informatyki, 497-498.

3 Por.: A. M. Mannion, Zmiany środowiska Zirmi. Historia środowiska przyrodniczego i kulturowego, tłum. Joanna Wibig, WN PWN, Warszawa 2001, 15-17.

4 Por. Maly slownik terminów i pojęć filozoficznych, oprac. A.Podsiad, Z.Więckowski, Warszawa 1983; 380-381; Słownik wyrazów obcych, red. naukowy J.Tokarski, Warszawa 1971, 723; J.Bocheński, O systemie. Wykład wygloszonych w ATK 1987-11-05, SPhCh 24/1988, 2/235-248; Problemy metodologii badań systemowych, tłum. E.Kaparisi, Warszawa 1973; S.Młynarki, Elemnty teorii systemów i cybernetyki, Warszawa 1974; Ogólna teoria systemów, pod. red. G.J.Klira, tlum. C.Bergman, Warszawa 1976; W.Sadowski, Podstawy ogólnej teorii systemów. Analiza logiczno-metodologiczna, tłum. A.Lewicka, Warszawa 1978; L. von Bartalanffy, Ogólna teoria systemów. Podstawy, rozwój, zastosowania, tłum. E.Waydyłłów-Woźniak, Warszawa 1984; M.Lubański, Informacja - system, w: M.Heller, M.Lubański, S.W.Ślaga, Zagadnienia filozoficzne wspótczesnej nauki, Warszawa $1982^{2}$, 14-70; Nauka - technika-system, pod red. W.Gasparskiego i D.Miller, Wroclaw 1981. 
Józef M. Dołęga

(gr. systema) i podkreśla taki układ elementów, który tworzy pewną całość uwarunkowaną stałym ładem jego części składowych w świecie realnym lub w sferze poznania ludzkiego. System stanowi całość, w której elementy są powiązane z sobą relacjami oddziaływania i stanowią jego strukturę. Każdy system otwarty ma swoje otoczenie. W przyrodzie i w poznaniu ludzkim występują przede wszystkim systemy otwarte. Otoczenie jest to rzeczywistość, która wchodzi lub może wchodzić w relacje $z$ systemem;

- aspelkt teoretyczny ekofilozofii oznacza poznanie teoretyczne ekosystemu na różnych poziomach złożoności;

- aspekt praktyczny ekofilozofii oznacza różnego rodzaju zastosowania nauki w ekosystemie, np. sozotechnika.

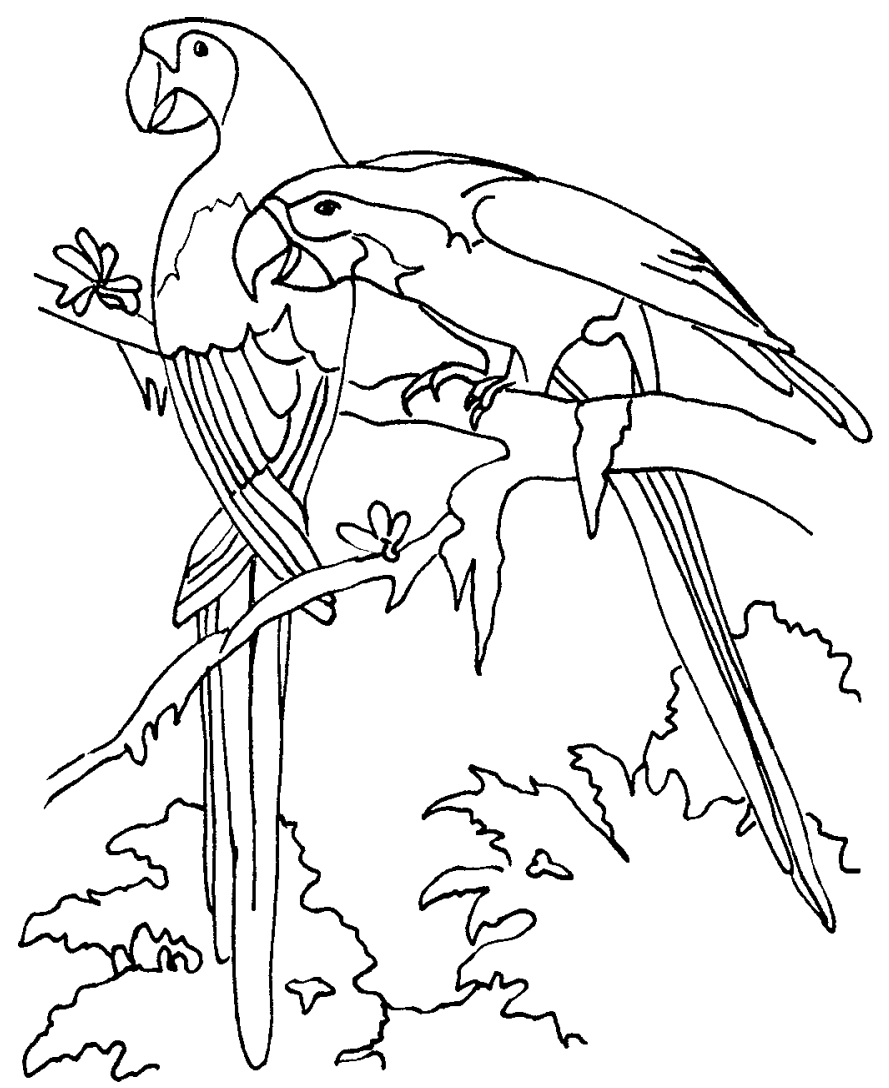

Rys. Dorota Maleszewska

502 